\title{
ANALISIS KINERJA PT PERKEBUNAN NUSANTARA III (PERSERO) MENGGUNAKAN METODE BALANCE SCORECARD
}

\author{
Supriyanto ${ }^{1 *}$, Desi Indah Sari ${ }^{2}$, Saiful Bahgia ${ }^{3}$, Sisca Mediyanti ${ }^{4}$, Josi Farmiati ${ }^{5}$ \\ ${ }^{1}$ Program Studi Administrasi Bisnis, Politeknik LP3I Medan \\ ${ }^{2}$ Program Studi Akuntansi, Politeknik LP3I Medan \\ ${ }^{3,4}$ Program Studi Akuntansi, Politeknik Kutaraja \\ ${ }^{5}$ Program Studi Administrasi Perkantoran, Politeknik Kutaraja \\ Telp. 0651- 8016378 \\ *Email: faiziqameira@gmail.com
}

\begin{abstract}
ABSTRAK
Pengukuran kinerja perusahaan salahsatunya menggunakan metode balance scorecard. Metode Balance scorecard memiliki 4 (empat) perspektif, namun pada penelitian ini hanya menggunakan prespektif keuangan saja. Tujuan penelitian ini adalah untuk mengetahui kinerja PT Perkebunan Nusantara III (Persero), dengan meggunakan metode Balanced Score Card. Jenis data yang digunakan adalah data sekunder yaitu data yang diperoleh melalui laporan keuangan. Metode analisis data yang digunakan adalah deskriptif kuantitatif yaitu mengelola data berupa angka-angka. Berdasarkan hasil penelitian yang dilakukan dari tahun 2012-2016 pada tahun 2012-2014 semua stabil namun pada tahun 2015 terjadi penurunan yang terlihat pada current ratio dan 2016 kembali stabil, sehingga dapat disimpulkan bahwa kinerja keuangan PT Perkebunan Nusantara III (Persero) dalam keadaan sehat.
\end{abstract}

\section{Kata Kunci : Balanced Scorecard, Kinerja Keuangan}

\section{PENDAHULUAN}

\section{Latar Belakang}

Sebagai institusi komersial perusahaan BUMN di Indonesia dituntut dapat kompetitif dan mampu menghasilkan laba serta dapat memberikan manfaat bagi stakeholder. Selain itu yang perlu diperhatikan adalah peningkatan efesiensi dan daya saing. Faktor penting dalam meningkatkan daya saing suatu perusahaan terletak pada unsur keuangannya. Berdasarkan laporan keuangan dari suatu perusahaan yang digunakan menilai kinerja laporan keuangan dapat memberikan gambaran terhadap posisi finansial perusahaan serta memberikan informasi tentang kondisi kesehatan keuangan perusahaan.

Berdasarkan penelitian yang dilakukan oleh Yuniawati (2014) berjudul "Analisis Penerapan Balance Scorecard Sebagai Pengukur Kinerja Pada PT Perkebunan Nusantara X (Persero)" diketahui bahwa kinerja perusahaan pada perspektif keuangan menunjukan adanya peningkatan kepuasan pelanggan, dan pada perspektif keuangan menunjukan adanya penurunan pendapatan perusahaan. Perbedaan penelitian sebelumnya adalah menggunakan empat perspektif yaitu perspektif keuangan, pelanggan, proses bisnis internal serta pembelajaran dan pertumbuhan sedangkan penelitian yang dilakukan difokuskan pada perspektif keuangan PT
Perkebunan Nusantara III (Persero), dengan pertimbangan bahwa PT Perkebunan Nusantara III (Persero) merupakan perusahaan BUMN perkebunan yang bergerak dalam bidang usaha perkebunan, pengolahan, dan pemasaran hasil perkebunan. Melalui pra penelitian yang dilakukan, berdasarkan laporan keuangan pada tahun 2015 diketahui current rasio mengalami penurunan. Sehingga perlu dilakukan suatu analisis berdasarkan aspek keuangan.

\section{LANDASAN TEORI}

\section{Pengertian Kinerja}

Perusahaan yang berskala besar cenderung lebih dikenal masyarakat sehingga informasi mengenai prospek perusahaan berskala besar lebih mudah diperoleh investor daripada perusahaan berskala kecil (Ramadana, 2018). Dalam persaingan yang terbuka dan kompetitif sebagai dampak dari globalisasi, pembangunan yang mendorong pertumbuhan perekonomian suatu negara menjadi sesuatu yang sangat penting. Pertumbuhan ekonomi tentunya membutuhkan indikator yang jelas sehingga dapat tergambarkan pasang surutnya perekonomian sebuah negara (Supriyanto, 2013). Selanjutnya Sudarmanto (2014) Akhirakhir ini kinerja telah menjadi teknologi atau konsep yang sering dipakai orang dalam berbagai pembahasan dan pembicaraan, 
khususnya dalam kerangka mendorong keberhasilan organisasi atau sumber daya manusia. Secara umum kinerja didefinikasikan sebagai suatu tampilan keadaan secara utuh atau prestasi yang dipengaruhi oleh kegiatan operasional lembaga dalam memanfaatkan sumber daya-sumber daya.

Supriyanto dan Lestari (2015) menyatakan bahwa setiap perusahaan bertujuan untuk memaksimalkan kekayaan dari pemegang sahamnya. Pengukuran kinerja keuangan perusahaan diperlukan untuk menentukan keberhasilan dalam mencapai tujuan tersebut.

Menurut Bastian (Sari, 2015) kinerja adalah gambaran mengenai tingkat pencapaian pelaksaan suatu kegiatan/ program/ kebijaksanaandalam mewujudkan sasaran, tujuan, misis dan visis organisasi yang tertuang dalam perumusan skema strategis (strategic planning) suatu organisasi .secara umum dapat dikatakan bahwa kinerja yang dapat dicapai oleh organisasi pada periode tertentu.

\section{Pengertian Pengukuran Kinerja}

Pertumbuhan ekonomi tentunya membutuhkan indikator yang jelas sehingga dapat tergambarkan pasang surutnya perekonomian sebuah negara. Salah satu indikator yang digunakan adalah pertumbuhan sektor keuangan yang stabil dan mantap. Menurut Bastian (Sari, 2015) Pengukuran Kinerja adalah suatu alat manajemen untuk meningkatkan kualitas pengambilan keputusan dan akuntabilitas,dengan demikian pengukuran organisasi merupakan dasar reasonable untuk pengambilan keputusan. Sedangkan Rangkuti (Rumintjap, 2013), menyatakan pengukuran kinerja merupakan suatu proses penilaian kemajuan pekerjaan terhadap tujuan serta sasaran yang telah ditentukan sebelumnya, termasuk informasi atas:

\section{Penilaian Kinerja}

Menurut Sukses (2017) Melakukan penilaian kinerja dalam suatu unit bisnis organisasi tentunya akan dilakukan dengan harapan agar hasil penilaian kinerja tersebut dapat digunakan sebagai cara menilai kemajuan kerja karyawan yang berdampak pada kemajuan suatu organisasi.

\section{Pengertian Balance scorecard}

Mardiasmo (2012) "Balance scorecard merupakan alat ukur yang dapat menambahkan keyakinan terhadap kualitas proses pengendalian manajemen. Teknik pengukuran kinerja yang komprehensif tidak hanya di ukur dari aspek keuangan saja, akan tetapi juga aspek non keuangannya, pengukuran kinerja dengan metode balance scorecard melibatkan empat aspek, yaitu: keuangan, pelanggan, proses bisnis internal serta pembelajaran dan pertumbuhan." Menurut Sukses (2017) adapun kekurangan balance scorecard membuat dan memasukkan ukuran dan system manajemen baru ke organisasi sangatlah rumit dan rentan sebagai berikut :

1. Balance scorecard belum dapat memberikan dan menetapkan bagaimana menyusun suatu system kompensasi sebagai tindak lanjut dari suatu penilaian kinerja yang di lakukan organisasi.

2. Membutuhkan biaya yang cukup besar seta tenaga ahli yang mumpuni untuk melakukan penilaian kinerja.

3. Standar baku atas hasil penilaian kinerja organisasi dengan metode balance scorecard belum tersedia sehingga setiap organisasi hanya dapat meraba-raba dan memberikan standar pengkuran sendiri atas penilaian kinerja.

\section{Perspektif Keuangan}

Salah satu pilar kegiatan ekonomi di Indonesia yang dikenal adalah Badan Usaha Milik Negara (BUMN). BUMN diharapkan akan mampu mendukung terhadap upaya perwujudan kesejahteraan sosial (.Menurut Sukses (2017) dalam perspektif ini, kinerja keuangan tetap digunakan untuk mengukur apakah dalam strategi organisasi, implementasi strategi hingga pelaksanaan akan membawa dampak positif bagi organisasi. Setiap pengukuran pasti akan memiliki hubungan sebab akibat yang diharapkan nantinya akan dapat meningkatkan kinerja keuangan organisasi.

Prespektif ini terdiri dari beberapa ukuran utama :

1. Retrun on Investment (ROI)

$$
\begin{aligned}
\mathrm{ROI} & =\frac{\text { EBIT }+ \text { PENYUSUTAN }}{\text { CAPITAL EMPLOYED }} \times 100 \% \\
\mathrm{ROI} & =\frac{1.984 .921 .478 .469}{7.158 .482 .302 .162} \times 100 \% \\
& =27,73
\end{aligned}
$$

Tabel 1. Return on Invesment

\begin{tabular}{|c|c|c|}
\hline \multirow{2}{*}{ ROI } & \multicolumn{2}{|c|}{ SKOR } \\
\cline { 2 - 3 } & Infra & Non Infra \\
\hline $18<\mathrm{ROI}$ & 10 & 15 \\
\hline $15<\mathrm{ROI} \leq 18$ & 9 & 13,5 \\
\hline $13<\mathrm{ROI} \leq 15$ & 8 & 12 \\
\hline $12<\mathrm{ROI} \leq 13$ & 7 & 10,5 \\
\hline $10<\mathrm{ROI} \leq 12$ & 6 & 9 \\
\hline $9<\mathrm{ROI} \leq 10,5$ & 5 & 7,5 \\
\hline $7<\mathrm{ROI} \leq 9$ & 4 & 6 \\
\hline
\end{tabular}




\begin{tabular}{|c|c|c|}
$5<\mathrm{ROI} \leq 7$ & 3,5 & 5 \\
\hline $3<\mathrm{ROI} \leq 5$ & 3 & 4 \\
\hline $1<\mathrm{ROI} \leq 3$ & 2,5 & 3 \\
\hline $0<\mathrm{ROI} \leq 1$ & 2 & 2 \\
\hline $\mathrm{ROI}<0$ & 0 & 1 \\
\hline
\end{tabular}

Sumber : keputusan menteri badan usaha milik negara : 100/MBU/2002

2. Retrun on Equity (ROE)

$$
\begin{aligned}
\mathrm{ROE} & =\frac{\text { LABA SETELAH PAJAK }}{M O D A L S E N D I R I} \times 100 \% \\
\mathrm{ROE} & =\frac{1.241 .878 .781 .308}{1.320 .783 .992 .983} \times 100 \% \\
& =94,03
\end{aligned}
$$

Tabel 2. Return on Equity

\begin{tabular}{|c|c|c|}
\hline \multirow{2}{*}{ ROE } & \multicolumn{2}{|c|}{ Skor } \\
\cline { 2 - 3 } & Infra & Non Infra \\
\hline $15<\mathrm{ROE}$ & 15 & 20 \\
\hline $13<\mathrm{ROE} \leq 15$ & 13,5 & 18 \\
\hline $11<\mathrm{ROE} \leq 13$ & 12 & 16 \\
\hline $9<\mathrm{ROE} \leq 11$ & 10,5 & 14 \\
\hline $7,9<\mathrm{ROE} \leq 9$ & 9 & 12 \\
\hline $6,6<\mathrm{ROE} \leq 7,9$ & 7,5 & 10 \\
\hline $5,3<\mathrm{ROE} \leq 6,6$ & 6 & 8,5 \\
\hline $4<\mathrm{ROE} \leq 5,3$ & 5 & 7 \\
\hline $2,5<\mathrm{ROE} \leq 4$ & 4 & 5,5 \\
\hline $1<\mathrm{ROE} \leq 2,5$ & 3 & 4 \\
\hline $0<\mathrm{ROE} \leq 1$ & 1,5 & 2 \\
\hline $\mathrm{ROE}<0$ & 1 & 0 \\
\hline
\end{tabular}

Sumber : keputusan menteri badan usaha milik negara : 100/MBU/2002

\section{Cash Ratio (CR)}

$$
\begin{gathered}
\mathrm{CR}=\frac{K A S+B A N K+\text { SURAT BERHARGA }}{U T A N G \text { LANCAR }} \times 100 \% \\
\mathrm{R}=\frac{574.584 .050+1.581 .318 .530 .730+50.097 .067 .908}{2.135 .704 .102 .534} \times 100 \%
\end{gathered}
$$

$$
=91,89
$$

\begin{tabular}{|c|c|c|}
\hline \multirow{2}{*}{$\begin{array}{l}\text { Current Ratio }=\mathrm{x} \\
\text { (\%) }\end{array}$} & \multicolumn{2}{|c|}{$\begin{array}{c}\text { Sko } \\
\mathrm{n}\end{array}$} \\
\cline { 2 - 3 } & Infra & $\begin{array}{c}\text { Non } \\
\text { Infra }\end{array}$ \\
\hline $125<=\mathrm{x}$ & 3 & 5 \\
\hline $110<=\mathrm{x}<125$ & 2,5 & 4 \\
\hline $100<=\mathrm{x}<110$ & 2 & 3 \\
\hline $95<=\mathrm{x}<100$ & 1,5 & 2 \\
\hline $90<=\mathrm{x}<95$ & 1 & 1 \\
\hline $\mathrm{x}<$ & 0 & 0 \\
90 & & \\
\hline
\end{tabular}

Sumber : keputusan menteri badan usaha milik negara : 100/MBU/2002

\section{Current Ratio}

Tabel 3. Current Ratio

\begin{tabular}{|c|c|c|}
\hline \multirow{2}{*}{ Current Rasio } & \multicolumn{2}{|c|}{ SKOR } \\
\cline { 2 - 3 } & Infra & Non Infra \\
\hline $125 \leq \mathrm{x}$ & 3 & 5 \\
\hline $110 \leq \mathrm{x}<125$ & 2,5 & 4 \\
\hline $100 \leq \mathrm{x}<110$ & 2 & 3 \\
\hline $95 \leq \mathrm{x}<100$ & 1,5 & 2 \\
\hline $90 \leq \mathrm{x}<95$ & 1 & 1 \\
\hline $\mathrm{x}<90$ & 0 & 0 \\
\hline
\end{tabular}

Sumber : keputusan menteri badan usaha milik negara : 100/MBU/2002

5. Collection Period (CP)

$$
\begin{aligned}
\mathrm{CP} & =\frac{\text { PIUTANG USAHA }}{\text { TOTAL PENDAPATAN USAHA }} \times 365 \text { hari } \\
\mathrm{CP} & =\frac{142.000 .270 .196}{6.497 .937 .025 .444} \times 365 \text { HARI } \\
& =7,98
\end{aligned}
$$

Tabel 4. Collection Period

\begin{tabular}{|c|c|c|c|}
\hline \multirow{2}{*}{$\mathrm{CP}$} & \multirow{2}{*}{$\begin{array}{c}\text { perbaikan } \\
\mathrm{x} \text { (hari) }\end{array}$} & \multicolumn{2}{|c|}{ SKOR } \\
\cline { 3 - 4 } & & $\begin{array}{c}\text { Non } \\
\text { Infra }\end{array}$ \\
\hline $\mathrm{x} \leq 60$ & $\mathrm{X}>35$ & 4 & 5 \\
\hline $60<\mathrm{x} \leq 90$ & $30<\mathrm{X} \leq 35$ & 3,5 & 4,5 \\
\hline $90<\mathrm{X} \leq 120$ & $25<\mathrm{X} \leq 30$ & 3 & 4 \\
\hline $\begin{array}{c}120<\mathrm{X} \leq \\
150\end{array}$ & $20<\mathrm{X} \leq 25$ & 2,5 & 3,5 \\
\hline $\begin{array}{c}150<\mathrm{X} \leq \\
180\end{array}$ & $15<\mathrm{X} \leq 20$ & 2 & 3 \\
\hline $\begin{array}{c}180<\mathrm{X} \leq \\
210\end{array}$ & $10<\mathrm{X} \leq 15$ & 1,6 & 2,4 \\
\hline $\begin{array}{c}210<\mathrm{X} \leq \\
240\end{array}$ & $6<\mathrm{X} \leq 10$ & 1,2 & 1,8 \\
\hline $\begin{array}{c}240<\mathrm{X} \leq \\
270\end{array}$ & $3<\mathrm{X} \leq 6$ & 0,8 & 1,2 \\
\hline $\begin{array}{c}270<\mathrm{X} \leq \\
300\end{array}$ & $1<\mathrm{X} \leq 3$ & 0,4 & 0,6 \\
\hline $300<\mathrm{X}$ & $0<\mathrm{X} \leq 1$ & 0 & 0 \\
\hline
\end{tabular}

Sumber : keputusan menteri badan usaha milik negara : 100/MBU/2002

6. Inventory Turn Over (ITO)

$$
\begin{aligned}
\mathrm{ITO}= & \frac{\text { TOTAL PERSEDIAAN }}{\text { TOTAL PENDAPATAN USAHA (PENJUALAN BERSIH })} \times \\
\mathrm{ITO} & =\frac{200.916 .968 .963}{6.497 .937 .025 .444} \times 100 \% \\
& =11,29
\end{aligned}
$$

Tabel 5. Perputaran Persediaan

\begin{tabular}{|c|c|c|c|}
\hline \multirow{2}{*}{$\mathrm{CP}$} & \multirow{2}{*}{$\begin{array}{c}\text { perbaikan } \\
\mathrm{x} \text { (hari) }\end{array}$} & \multicolumn{2}{|c|}{ SKOR } \\
\cline { 3 - 4 } & & Infra & $\begin{array}{c}\text { Non } \\
\text { Infra }\end{array}$ \\
\hline $\mathrm{x} \leq 60$ & $\mathrm{X}>35$ & 4 & 5 \\
\hline $60<\mathrm{x} \leq 90$ & $30<\mathrm{X} \leq 35$ & 3,5 & 4,5 \\
\hline $90<\mathrm{x} \leq 120$ & $25<\mathrm{X} \leq 30$ & 3 & 4 \\
\hline
\end{tabular}




\begin{tabular}{|c|c|c|c|}
$120<x \leq 150$ & $20<X \leq 25$ & 2,5 & 3,5 \\
\hline $150<x \leq 180$ & $15<X \leq 20$ & 2 & 3 \\
\hline $180<x \leq 210$ & $10<X \leq 15$ & 1,6 & 2,4 \\
\hline $210<x \leq 240$ & $6<X \leq 10$ & 1,2 & 1,8 \\
\hline $240<x \leq 270$ & $3<X \leq 6$ & 0,8 & 1,2 \\
\hline $270<x \leq 300$ & $1<X \leq 3$ & 0,4 & 0,6 \\
\hline $300<x$ & $0<X \leq 1$ & 0 & 0 \\
\hline
\end{tabular}

Sumber : keputusan menteri badan usaha milik negara : 100/MBU/2002

\section{Total Asset Turn Over (TATO)}

$$
\begin{aligned}
\text { TATO }= & \frac{\text { TOTAL PEDAPATAN }}{\text { CAPITAL EMPLOYED }} \times 100 \% \\
\text { TATO }= & \frac{6.716 .773 .681 .096}{7.158 .482 .302 .162} \times 100 \% \\
& =93,83 \%
\end{aligned}
$$

Tabel 6. Total Asset Turn Over

\begin{tabular}{|c|c|c|c|}
\hline \multirow{2}{*}{$\%$} & \multirow{2}{*}{$\begin{array}{c}\text { Perbaikan } \\
=\mathrm{x}(\%)\end{array}$} & \multicolumn{2}{|c|}{ SKOR } \\
\cline { 3 - 4 } & & Infra & $\begin{array}{c}\text { Non } \\
\text { Infra }\end{array}$ \\
\hline $120<\mathrm{X}$ & $20<\mathrm{X}$ & 4 & 5 \\
\hline $\begin{array}{c}105<\mathrm{X} \leq \\
120\end{array}$ & $15<\mathrm{X} \leq 20$ & 3,5 & 4,5 \\
\hline $90<\mathrm{X} \leq 105$ & $10<\mathrm{X} \leq 15$ & 3 & 4 \\
\hline $75<\mathrm{X} \leq 90$ & $5<\mathrm{X} \leq 10$ & 2,5 & 3,5 \\
\hline $60<\mathrm{x} \leq 75$ & $0<\mathrm{X}<=5$ & 2 & 3 \\
\hline $40<\mathrm{x} \leq 60$ & $\mathrm{X} \leq 0$ & 1,5 & 2,5 \\
\hline $20<\mathrm{x} \leq 40$ & $\mathrm{X}<0$ & 1 & 2 \\
\hline $\mathrm{x} \leq 20$ & $\mathrm{X}<0$ & 0,5 & 1,5 \\
\hline
\end{tabular}

Sumber : keputusan menteri badan usaha milik negara : 100/MBU/2002

8. Indikator dan Bobot Bobot Aspek Keuangan

Tabel 8. Industri Rasio

\begin{tabular}{|l|c|c|}
\hline \multirow{2}{*}{\multicolumn{1}{|c|}{ Indikator penilaian }} & \multicolumn{2}{|c|}{ Skor } \\
\cline { 2 - 3 } & infra & $\begin{array}{c}\text { Non } \\
\text { infra }\end{array}$ \\
\hline $\begin{array}{l}\text { Imbalan ke pada } \\
\text { pemegang saham (ROE) }\end{array}$ & 15 & 20 \\
\hline Imbalan Investasi (ROI) & 10 & 15 \\
\hline Rasio kas & 3 & 5 \\
\hline Rasio lancar & 4 & 5 \\
\hline Collection Periods & 4 & 5 \\
\hline Perputaran persediaan & 4 & 5 \\
\hline perputarantotal asset & 4 & 5 \\
\hline $\begin{array}{l}\text { Rasio modal sendiri } \\
\text { terhadap total aktiva }\end{array}$ & 6 & 10 \\
\hline \multicolumn{1}{|c|}{ Total bobot } & 50 & 70 \\
\hline
\end{tabular}

Sumber : SK Menteri BUMN 100/MBU/2002.

Berdasarkan tabel diatas dapat dijelaskan bahwa :
1. Imbalan ke pada pemegang saham dapat dijelaskan bahwa untuk infrastruktur diatas 15 lebih baik dan dibawah 15 tidak baik. Sedangkan untuk infrastruktur diatas 20 lebih baik dan dibawah 20 tidak baik. Namun jika perusahaan mencapai angka 15 untuk infra dan 20 non infra maka perusahaan dianggap normal.

2. Imbalan ke pada pemegang saham dapat dijelaskan bahwa untuk infrastruktur diatas 10 lebih baik dan dibawah 15 tidak bail. Namun jika perusahaan mencapai angka 10 untuk infrea dan 15 untuk non infra maka perusahaan dianggap normal.

3. Imbalan ke pada pemegang saham dapat dijelaskan bahwa untuk infratruktur di atas 3 lebih baik dan dibawah 3 tidak baik. Namun jika perusahaan mencapai angka 3 untuk infra dan 5 non infra maka perusahaan dianggap normal.

4. Imbalan ke pada pemegang saham dapat dijelaskan bahwa untuk infrastruktur diatas 5 lebih baik dan dibawah 4 tidak baik. Sedangkan untuk infrastruktur diatas 5 lebih baik dan dibawah 5 tidak baik. Namun jika perusahaan angka 4 untuk infra dan 5 untuk non infra maka perusahaan dianggap normal.

5. Imbalan kepada pemegang saham dapat dijelaskan bahwa untuk infrastruktur diatas 4 lebih baik dan dibawah 5 tidak baik. Sedangkan untuk infrastruktur diatas 5 lebuh baik dan dibawah 5 tidak baik. Namun jika perusahaan mencapai angka 4 untuk infra dan 5 non infra maka perusahaan dianggap normal.

6. Imbalan kepada pemegang saham dapat dijelaskan bahwa untuk infrastruktur diatas 4 lebih baik dan dibawah 4 tidak baik. Sedangkan untuk infrastruktur diatas 5 lebih baik dan dibawah 5 tidak baik. Namun jika perusahaan mencapai angka angka 4 untuk infra dan 5 non infra maka perusahaan dianggap normal.

7. Imbalan kepada pemegang saham dapat dijelaskan bahwa untuk infrastruktur diatas 4 lebih baik dan dibawah 4 tidak baik. Sedangkan untuk infrastruktur diatas 5 lebih baik dan dibawah 5 tidak baik. Namun jika perusahaan mencapai angka angka 4 untuk infra dan 5 non infra maka perusahaan dianggap normal.

8. Imbalan kepada pemegang saham dapat dijelaskan bahwa infrastruktur diatas 6 lebih baik dan dibawah 6 tidak baik. Sedangkan untuk infrastruktur diatas 10 lebih baik dan dibawah 10 tidak baik. Namun jika perusahaan mencapai angka 6 untuk infra dan non infra 10 maka perusahaan dianggap normal. 


\section{METODE PENELITIAN}

Teknik analisis data yang digunakan dalam penilitian ini adalah deskriptif kuantitaf yang berupa angka-angka. Menurut Sujarweni (2014) kuantitatif adalah jenis penelitian yang menghasilkan penemuan-penemuan yang dapat dicapai (diperboleh) dengan menggunakan prosedur-prosedur statistic atau cara-cara lain dari kuantitatif (pengukuran).

\section{HASIL DAN PEMBAHASAN}

\section{Hasil Penelitian}

PT Perkebunan Nusantara III (Persero) yang bergerak dalam bidang perkebunan kelapa sawit dan karet dengan lahan seluar $161.638,38$ ha yg terbesar di Sumatera Utara. Dalam pengelolahan Organisasi dibagi menjadi 16 bgaian, 8 distrik manager, 34 unit kebun, 11 unit PKS dan 5 unit Rumah Sakit Serta didukung oleh karyawan sendiri sebanyak 28.469 orang. PT Perkebunan Nusantara III (Persero) mengelola dua jenis komoditi perkebunan berupa kelapa sawit dan karet yang dilengkapi dengan sarana pengolahan dan industri hilir kelapa sawit.

\section{Perspektif keuangan}

Adapun ukuran-ukuran yang digunakan untuk menghitung kinerja keuangan pada PT Perkebunan Nusantara III (Persero) adalah sebagai berikut :

\section{Return on Invesment}

$$
\mathrm{ROI}=\frac{\text { EBIT }+ \text { PENYUSUTAN }}{\text { CAPITAL EMPLOYED }} \times 100 \%
$$

Tabel 9. Return on Invesment Tahun 20122016

(dalam jutaan)

\begin{tabular}{|c|c|c|c|c|}
\hline $\begin{array}{c}\text { Tahu } \\
\mathrm{n}\end{array}$ & \multicolumn{1}{|c|}{ EBIT } & $\begin{array}{c}\text { Capital } \\
\text { Employed }\end{array}$ & $\begin{array}{l}\text { ROI } \\
(\%)\end{array}$ & Skor \\
\hline 2012 & 1.584 .744 & 7.866 .520$. & $\begin{array}{l}20,1 \\
4\end{array}$ & 15.00 \\
\hline 2013 & 1.077 .202 & 8.354 .616 & $\begin{array}{l}12,8 \\
9\end{array}$ & 10.50 \\
\hline 2014 & 1.253 .115 & 12.233 .29 & $\begin{array}{l}10,2 \\
4\end{array}$ & 7.50 \\
\hline 2015 & 1.407 .776 & $\begin{array}{l}42.455 .02 \\
2\end{array}$ & $\begin{array}{l}3,31 \\
6\end{array}$ & 4.00 \\
\hline 2016 & 1.693 .530 & 13.088 .92 & $\begin{array}{l}12,9 \\
4\end{array}$ & 10.55 \\
\hline
\end{tabular}

Sumber: Data sekunder yang diolah

Berdasarkan tabel 9 dapat dianalisa Return on Investment selama tahun 2012-2014 menunjukan peningkatan sedangkan pada tahun 2015 mengalami penurunan. Besarnya return on investment, PT Perkebunan Nusantara III (Persero) ini dipengaruhi oleh laba bersih dan total aktiva, memperbesar laba berkaitan dengan effesiensinya sedangkan aktiva berkaitan dengan kebijakan investasi dan berbagai aktiva, baik aktiva tetap maupun aktiva lancar dan skor menjelaskan apakan yang direalisasikan sesuai dengan yang di anggarkan. Pada tahun 2015 rasio ini mengalami penurunan dibandingkan pada tahun 2014 yang memperoleh $8,09 \%$, kondisi ini menunjukan bahwa perusahaan mengalami penurunan kemampuan dalam menghasilkan laba yang bersumber dari modal sendiri.

\section{Return On Equity}

$$
\mathrm{ROE}=\frac{\text { LABA SETELAH PAJAK }}{\text { MODAL SENDIRI }} \times 100 \%
$$

Tabel 4.2 Return On Equity (ROE) Tahun 20122016 (Dalam jutaan rupiah)

\begin{tabular}{|c|c|c|l|c|}
\hline Tahun & $\begin{array}{c}\text { Laba } \\
\text { setelah } \\
\text { pajak }\end{array}$ & $\begin{array}{c}\text { Modal } \\
\text { Sendiri }\end{array}$ & $\begin{array}{c}\text { ROE } \\
\%\end{array}$ & SKOR \\
\hline 2012 & 862.994 & 1.538 .372 & 56,10 & 20.00 \\
\hline 2013 & 391.000 & 1.770 .562 & 22,08 & 20.00 \\
\hline 2014 & 438.978 & 5.426 .839 & 8,09 & 12.00 \\
\hline 2015 & 595.206 & 3.951 .884 & 1,75 & 4.00 \\
\hline 2016 & 583.620 & 4.381 .359$. & 13,32 & 18.00 \\
\hline
\end{tabular}

Sumber : Data Sekunder yang diolah

Berdasarkan tabel 4.2 maka skor yang diperoleh pada tahun 2012 mendapatkan 56\% sedangkan skor untuk menilai kinerja $20 \%$ maka ROI sudah termaksud utilisasi sebesar 56\%. Sedangkan pada tahun 2015 belum mengalamai utilisasi.

3. Cash Ratio

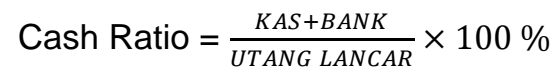

Tabel 4.3 Current Ratio Tahun 2012-2016

\begin{tabular}{|l|c|l|l|l|}
\hline Tahun & $\begin{array}{c}\text { Laba } \\
\text { setelah } \\
\text { pajak }\end{array}$ & $\begin{array}{c}\text { Modal } \\
\text { Sendiri }\end{array}$ & ROE \% & SKOR \\
\hline 2012 & 862.994 & 1.538 .372 & 56,10 & 20.00 \\
\hline 2013 & 390.969 & 1.770 .561 & 22,08 & 20.00 \\
\hline 2014 & 438.977 & 5.426 .839 & 8,08 & 12.00 \\
\hline 2015 & 595.206 & 33.950 .884 & 1,75 & 4.00 \\
\hline 2016 & 583.620 & 4.381 .358$. & 13,32 & 18.00 \\
\hline
\end{tabular}

Berdasarkan table 4.3 yang menjelaskan cash ratio telah di analisis dapat dilihat setiap tahunnya terjadi kenaikan setiap tahunnya dan 
dapat menjelaskan bahwa dapat membantu pada aspek keuangan. Pada tahun 2012 memperoleh nilai 103,41\%, 2013 memperoleh nilai $81,70 \%$, tahun 2014 memperoleh nilai 53,34\% tahun 2015 memperoleh nilai 3,32\%, tahun 2016 memperoleh nilai 32,09\%, menunjukan peningkatan pada tahun 20122014 dan 2016 namun di tahun pada tahun 2015 mengalami penurunan, hal ini menunjukan bahwa kas dan surat-surat berharga yang dimiliki perusahaan belum mampu melunasi kewajiban lancer.

4. Current Ratio (Cr. R)

$$
\mathrm{Cr} . \mathrm{R}=\frac{\text { ASSET LANCAR }}{\text { UTANG LANCAR }} \times 100 \%
$$

Tabel 10. Current Ratio (Cr.R) Tahun 2012-2016 (dalam jutaan rupiah)

\begin{tabular}{|l|l|l|r|r|}
\hline Tahun & $\begin{array}{l}\text { Aset } \\
\text { lancar }\end{array}$ & $\begin{array}{l}\text { Hutang } \\
\text { lancar }\end{array}$ & Cr.R\% & SKOR \\
\hline 2012 & 2.326 .765 & 1.715 .105 & 135,66 & 5.00 \\
\hline 2013 & 2.112 .986 & 1.779 .882 & 118,71 & 4.00 \\
\hline 2014 & 1.599 .868 & 2.197 .853 & 72,79 & - \\
\hline 2015 & 1.709 .756 & 2.011 .780 & 84,99 & - \\
\hline 2016 & 2.780 .774 & 2.013 .315 & 138,12 & 5.00 \\
\hline
\end{tabular}

Sumber : Data sekunder yang diolah

Berdasarkan tabel 10 menjelaskan bahwa Current Ratio dari tahun 2012-2016 mendapatkan skor diatas 5 dan ini menunjukan bahwa perusahaan dianggap normal. Pada tahun 2012 memperoleh nilai sebesar 135,66\%, pada tahun 2013 memperoleh nilai sebesar 118,7\%, pada tahun 2014 memperoleh nilai sebesar 72,79\%, pada tahun 2015 memperoleh nilai sebesar $85.01 \%$, pada tahun 2016 memperoleh nilai sebesar $138.12 \%$, pada tahun 2012-2015 mengalami penurunan kecuali pada tahun 2016 mengalami kenaikan sebesar $53,11 \%$, rasio ini menurun disebabkan oleh meningkatnya kewajiban lancar yang kenaikannya hampir dua kali lipat dari tahun yang lalu tidak sebanding dengan kenaikan aktiva lancar dan tingkat kemampuan perusahaan untuk memenuhi kewajiban lancar tidak sesuai yang diharapkan.

5. Collection Periods (CP)

$$
\text { CP }=\frac{\text { TOTAL PIUTANG USAHA }}{\text { PENJUALAN BERSIH }} \times 365 \%
$$

Tabel 11 Collection Periods (CP) Tahun 20122016 (dalam jutaan rupiah)

\begin{tabular}{|c|c|c|c|c|}
\hline Tahun & $\begin{array}{c}\text { Piutang } \\
\text { usaha }\end{array}$ & $\begin{array}{c}\text { penjualan } \\
\text { bersih }\end{array}$ & CP\% & SKOR \\
\hline 2012 & 71.751 & 5.946 .518 & 4,4 & 5.00 \\
\hline 2013 & 736.814 & 5.708 .476 & 0,05 & 5.00 \\
\hline 2014 & 404.770 & 6.232 .179 & 0,03 & 5.00 \\
\hline 2015 & 119.132 & 5.363 .366 & 0,01 & 5.00 \\
\hline 2016 & 132.337 & 5.847 .818 & 0,01 & 5.00 \\
\hline
\end{tabular}

Sumber : data sekunder yang di olah
Berdasarkan tabel 11, yang menjelaskan collection periods dari tahun 2012-2016 mendapatkan skor dibawah 5 dan ini menunjukan bahwa perusahaan dianggap kurang baik. Pada tahun 2012 nilai 56,10\%, 2013 nilai sebesar 22,08\%, 2014 nilai sebesar 1,24\%, 2015 mendapatkan nilai 3,32\% dan 2016 sebesar 12,94\%, ini menunjukan telah terjadi kenaikan namun pada tahun 2015 menurun, penurunan ini disebabkan kenaikan capital employed tidak sebanding dengan kenaikan ebit plus penyusutan lebih nilai capital employed banding dengan nilai ebit dan penyusutan tingkat pencapaian laba atas aktiva yang tidak diakibatkan oleh kenaikan total aktiva yang tidak diimbangi oleh kenaikan EBIT dan penyusutan. Rasio ini mengalami penurunan yang menyebabkan semakin lamanya tingkat waktu yang diperlukan untuk mengumpulkan piutang dan piutang disebabkan oleh penjualan barang-barang secara kredit dan hasil dari penjualan secara kredit netto dibagi dengan piutang rata-rata.

\section{Inventory Turn Over (ITO) ITO $=\frac{\text { TOTAL PERSEDIAAN }}{\text { PRNJUALAN BERSIH }} \times 365$}

Tabel 12 Inventory Turn Over Tahun 20122016 (dalam jutaan rupiah)

\begin{tabular}{|c|c|c|c|c|}
\hline Tahun & Persediaan & $\begin{array}{c}\text { Penjualan } \\
\text { Bersih }\end{array}$ & $\begin{array}{c}\text { ITO } \\
\%\end{array}$ & skor \\
\hline 2012 & 303.695 & 5.946 .518 & 18,64 & 5.00 \\
\hline 2013 & 251.038 & 5.708 .476 & 16,05 & 5.00 \\
\hline 2014 & 227.758 & 6.232 .179 & 13,34 & 5.00 \\
\hline 2015 & 179.436 & 5.363 .366 & 12,21 & 5.00 \\
\hline 2016 & 200.790 & 5.847 .818 & 12,53 & 5.00 \\
\hline
\end{tabular}

Berdasarkan atas penelitian pada Inventory Turn Over dari tahun 2012-2016 mendapatkan skor diatas 5 dan kondisi ini menunjukan bahwa perusahaan dianggap normal. Pada inventory turn over ini mengalami penurunan, hal ini menunjukan bahwa perusahaan memperlambat tingkat waktu yang dibutuhkan dalam menjual persediaan.

\section{Total Assets Turn Over}

$$
\text { TATO }=\frac{\text { TOTAL PENDAPATAN }}{\text { CAPITAL EMPLOYED }} \times 100
$$

Tabel 13. Total Aseets Turn Over (TATO) Tahun 2012-2016 (dalam jutaan rupiah)

\begin{tabular}{|l|r|r|c|}
\hline Tahun & Pendapatan & $\begin{array}{c}\text { Capital } \\
\text { Employed }\end{array}$ & TATO\% \\
\hline 2012 & 6.045 .395 & 7.866 .520 & 76,85 \\
\hline 2013 & 5.933 .374 & 8.354 .615 & 71,02 \\
\hline 2014 & 6.367 .286 & 12.233 .296 & 52,05 \\
\hline 2015 & 5.884 .496 & 42.455 .021 & 13,86 \\
\hline 2016 & 6.054 .733 & 13.088 .928 & 46,26 \\
\hline
\end{tabular}

sumber : Data Sekunder yang Diolah 
Berdasarkan perhitungan delapan indikator diatas dapat diketahui bahwa PT Perkebunan Nusantara III (Persero) mengalami keturunan. Pada tahun 2015 PT Perkebunan Nusantara III (Persero) memperoleh nilai sebesar 31,5\%. Pada tahun 2016 mengalami kenaikan sebesar $59 \%$, hal ini menunjukan bahwa perusahaan ini mengalami penurunan dalam tingkat kesehatan yaitu sebesar 27,5\% dengan predikat yang sama yaitu BBB "Kurang Sehat". Pada tahun 2015 terjadi penurunan yang drastic sebesar $13,86 \%$. Hal ini menunjukan bahwa aktiva yang dimiliki mengalami penurunan dalam menghasilkan laba.

\section{KESIMPULAN}

Berdasarkan pembahasan maka peneliti dapat menyimpulkan hal-hal sebagai berikut :

1. Berdasarkan rasio yang telah dihitung maka tingkat keuangan perusahaan pada tahun 2012-2013 sebesar $16 \%$, 2013-2014 sebesar $45 \%$, 2014-2015 sebesar $12 \%$, 2015-2016 sebesar $53 \%$.

2. Penurunan pada tahun 2015 dibandingkan dengan tahun sebelumnya terjadi pada penurunan current rasio dari tahun ke tahun ini disebabkan oleh meningkatnya kewajiban lancar yang kenaikannya hampir dua kali lipat dari tahun yang lalu, tidak berbanding lurus dengan kenaikan aktiva lancar .

\section{DAFTAR PUSTAKA}

Hanum, Z., \& Riswana, D. (2014). TINJAUAN KINERJA KARYAWAN PADA PERUSAHAAN BONGKAR MUAT PELABUHAN INDONESIA I CABANG BELAWAN. Jurnal Bis-A: Jurnal Bisnis Administrasi, 3(2), 67-70.

Hutajulu, S. M., \& Supriyanto, S. (2013). TINJAUAN PELAKSANAAN PELATIHAN DAN PENGEMBANGAN KARYAWAN PADA PT. INALUM KABUPATEN BATUBARA. Jurnal Bis-A: Jurnal Bisnis Administrasi, 2(2), 30-39.

Putra, R. E. (2014), Analisis Kinerja Perusahaan Dengan Metode Balance Scorecard, Jurnal Measure Vol.8 No.7

Ramadana, S. W. (2018). Beberapa Faktor yang Mempengaruhi Underpricing Saham Pada Perusahaan Yang Melakukan Initial Public Offering (IPO) Di Bursa Efek Indonesia. Jurnal Riset Inspirasi Manajemen dan Kewirausahaan, 2(2), 102-108.

Rumintjap, M. L. (2013), Penerapan Balance Scorecard Sebagai Tolok Ukur Pengukuran Kinerja di RSUD Noongan, Jurnal Emba Vol. 1 No.3
Sari, A. P. (2015) Penerapan Balance Scorecard Sebagai Alat Pengukuran Kinerja, Jurnal Ilmu \& Riset, Vol. 4 No. 11

Sihombing, I. K., \& Fitriani, N. (2015). HUBUNGAN INSENTIF (PREMI) TERHADAP MOTIVASI KERJA KARYAWAN PT. PERKEBUNAN NUSANTARA III (PERSERO) MEDAN. Jurnal Bis-A: Jurnal Bisnis Administrasi, 4(1), 08-16.

Sudarmanto. S. (2014) Kinerja dan Pengembangan SDM : Teori, Dimensi Pengukuran dan Implementasi Dalam Organisasi , Yogyakarta : Balai pustaka

Sudaryono. S. (2014) Aplikasi statistic Untuk Penelitian, Cetakan Pertama, Tanggerang : Lentera IImu Cendekia

Sujarweni, V. W. (2014) Metodologi Penelitian, Yogyakarta : Pustaka Baru Press

Sukses, R. A. (2017) Balance Scorecard, Cetakan 1, Jakarta : Swadaya Group

Supriyanto, S. (2013) Pengaruh Kinerja Keuangan Terhadap Pendapatan Saham Perbankan Di Bursa Efek Indonesia. Jurnal Bisnis Administrasi Volume 02, Nomor 01, 2013

Supriyanto, S. dan Lestari, W. (2015) Analisis Kinerja Keuangan Dengan Menggunakan Metode Economic Value Added Pada PT. Bank Mandiri (Persero), Tbk. Jurnal Bisnis Administrasi Volume 04, Nomor 01, 2015

Tika, M. P. (2012) Budaya Organisasi Dan Peningkatan Kinerja Perusahaan, Cetakan keempat, Jakarta : Sinar Grafika Offset

Ulfah, A. K. (2014). Implementasi Good Corporate Governance Dalam Meningkatkan Kualitas Pelayanan Pada Pt PLN Wilayah Aceh. Jurnal Administrasi Akuntansi: Program Pascasarjana Unsyiah, 3(3).

Yolanda, A., Ranita, S. V., Idris, I., \& Nurismilida, N. (2015). EFEKTIVITAS PENILAIAN PRESTASI KERJA KARYAWAN (STUDI KASUS: PTPN IV (PERSERO)-KEBUN TINJOWAN SIMALUNGUN). Jurnal Bis-A: Jurnal Bisnis Administrasi, 4(2), 69-74. 